REVISTA DE DERECHO UNED, NÚM. 28, 2021

\title{
EL DERECHO PENAL DEL RIESGO. APUNTES SOBRE SU APLICACIÓN EN EL ÁMBITO DE LA SEGURIDAD VIAL
}

\author{
THE CRIMINAL LAW OF RISK. NOTES ON ITS APPLICATION IN \\ THE FIELD OF ROAD SAFETY
}

José Antonio Mingorance SÁnchez

Doctor en Derecho y Ciencias Sociales por la

Universidad Nacional de Educación a Distancia (UNED)

Sumario: I. La inseguridad vial en la sociedad del riesgo. II. Teorías dobre la modernización del Derecho penal. II.1. Teorías de resistencia a la modernización del Derecho penal. II.2. Teorías favorables a la modernización del Derecho penal. III. El peligro en el Derecho penal del riesgo. III.1. El juicio de peligro y su incursión en el Derecho penal del tráfico. IV. Los delitos de peligro en la sociedad del riesgo. IV.1. Los delitos de peligro concreto. IV.2. Los delitos de peligro abstracto. V. Aproximación al bien jurídico protegido. V.1. El bien jurídico colectivo seguridad vial. VI. Conclusiones.

Resumen: El derecho subjetivo a la seguridad vial emerge con fuerza a lo largo del siglo xx en el marco de la denominada sociedad del riesgo, caracterizada por el impulso del desarrollo tecnológico y la aparición de nuevos usos sociales, con un incremento del tráfico rodado por las carreteras españolas y el consiguiente aumento de la siniestralidad vial. Y esta nueva realidad social va a promover una modernización del Derecho penal existente para adaptarlo a las nuevas demandas sociales de mayor control de estas actividades peligrosas, recurriendo para ello a la creación de nuevos bienes jurídicos supraindividuales y a la técnica legislativa de los delitos de peligro. Pero esta expansión del Derecho penal no puede suponer un 
abandono de los principios limitadores del ius puniendi del Estado, ni puede admitir la inclusión de cualquier conducta como merecedora de reproche penal, pudiendo encontrar actualmente algunos tipos recogidos en el Código Penal que presentan una difícil justificación como delitos contra la seguridad vial.

Abstract: The subjective right to drive safety emerged strongly throughout the twentieth century within the framework of the socalled risk society, characterized by the impulse of technological development and the appearance of new social uses, with an increase in traffic on Spanish roads and the consequent increase in road accidents. And this new social reality will promote a modernization of current criminal law in order to adapt it to the new social demands for greater control of these dangerous activities, to the creation of new supra-individual legal assets and to the legislative technique of dangerous crimes. However, this extension of the criminal law cannot suppose an infringement of the principles that limit the ius puniendi of the State, nor can it admit the inclusion of any conduct as deserving of criminal liability, being able to find currently some types included in the Penal Code that can hardly be justified as offences against road safety.

Palabras clave: Delitos de peligro. Sociedad del riesgo. Seguridad vial. Bienes supraindividuales.

Keywords: Dangerous offences. Risk society. Road safety. Supra-individual assets.

Recepción original:09-03-2021

Aceptación original:20-09-2021

\section{LA INSEGURIDAD VIAL EN LA SOCIEDAD DEL RIESGO}

El origen del problema que representa la siniestralidad vial podría centrarse en un 17 de agosto de 1896, cuando la señora Bridget Driscoll, de 44 años de edad y madre de dos hijos, se convirtió en la primera víctima mortal de un accidente de tráfico mientras iba caminando con su hija hacia un espectáculo de baile en el Crystal Palace de Londres. El coche que la arrolló iba a "gran velocidad", según afirmó algún testigo, circulando posiblemente a 12,8 $\mathrm{km} / \mathrm{h}$, encontrándose a los mandos del vehículo un joven que se dedicaba a dar paseos en el coche para mostrar el nuevo invento. En 
la investigación, el funcionario encargado afirmó: "esto no debe volver a ocurrir nunca jamás"1.

En España, en 1778 se dictaría un primer Real Decreto que instaba al gobierno a gestionar la seguridad y comodidad de los caminos y tránsitos para la fácil comunicación, al que le seguiría la Ordenanza para la conservación y policía de las carreteras generales de 1842. No obstante, la primera norma que se va a ocupar del tráfico o circulación vial de manera autónoma va a ser la Real Orden de 31 de julio de 1897, que sería sustituida y complementada por otra el 17 de septiembre de 1900 que aprobaría el Reglamento para el Servicio de Coches Automóviles por las Carreteras del Estado².

Será más tarde, el 25 de septiembre de 1934, cuando se publique el primer Código de Circulación, comenzando paralelamente una trágica cifra de siniestralidad en carretera que en el año 1960 -primer año en que se tienen cifras de las series históricas por parte de la Dirección General de Tráfico (DGT)- se situaba ya en 2.288 personas fallecidas, alcanzando el pico de mortalidad por accidentes de tráfico en el año 1989, con la trágica cifra de 9.344 fallecidos en las carreteras españolas ${ }^{3}$.

Esta dramática cifra ha venido descendiendo desde entonces de manera más o menos acentuada dependiendo de las diversas medidas adoptadas por los diferentes gobiernos en todos los ámbitos, destacando el periodo entre el 2005-2008.

Fue en este trienio en el que se "incluyeron hitos tan importantes como: la aprobación de la Ley del Permiso de Conducir por Puntos,

1 Véase Organización Mundial de la SAlud, La seguridad vial no es accidental: folleto para el Día Mundial de la Salud, 7 de abril de 2004. Ginebra: Organización Mundial de la Salud, 2004, pág. 2. Recuperado el 4 de agosto de 2021 de http://apps. who.int/iris/handle/10665/68504.

2 Véase el sitio web de la Dirección General de Tráfico consultado el 4 de agosto de 2021 de http://www.dgt.es/es/la-dgt/quienes-somos/historia/. El primer vehículo matriculado sería un Clement, registrado oficialmente en Baleares el día 11 de octubre de 1900 con matrícula PM-1, y el segundo un Torneau en Salamanca, el día 7 de diciembre del mismo año. Entre 1900 y 1950 se sucederían las matriculaciones en progresión geométrica, rebasando el millar en 1970 (1.171 vehículos matriculados), para alcanzar en 1950 casi medio millón (466.474 vehículos matriculados), de los que habría que deducir 271.524 bajas producidas en ese periodo y que supuso una reducción del $58,21 \%$ en esos primeros cincuenta años, una cifra moderada según criterios de la propia DGT.

3 Dirección General de Tráfico, Servicio de Estadística. Observatorio Nacional de Seguridad Vial, Anuario estadístico de accidentes 2018, pág. 6. Recuperado el 4 de agosto de 2021 de https:/www.dgt.es/Galerias/seguridad-vial/estadisticas-e-indicadores/publicaciones/anuario-estadistico-de-accidentes/Anuario-estadistico-deaccidentes-2019.pdf. 
la presentación del Plan de instalación de Radares Fijos en carretera, la creación de la figura del Fiscal de Sala Coordinador de Seguridad Vial o la aprobación de Ley Orgánica 15/2007, que introdujo importantes modificaciones en el Código Penal (CP) en materia de Seguridad Vial"4. A todo lo anterior habría que añadir un importante incremento de 1.500 agentes en la Agrupación de Tráfico de la Guardia Civil con funciones casi en exclusiva de vigilancia y control del tráfico y la seguridad vial.

Estas y otras medidas han conseguido reducir las cifras de fallecidos en accidentes de tráfico hasta los 870 en el año $2020^{5}$. La cifra más baja de la historia que sin embargo hay que enmarcar en el contexto de un año atípico para la movilidad, caracterizado por las restricciones impuestas tras la declaración del estado de alarma del 14 de marzo de 2020 y el confinamiento general de la población para hacer frente a la crisis sanitaria originada por el COVID-19.

El accidente puede ser considerado de manera genérica como un suceso fortuito o eventual, fruto del destino o de la casualidad, comúnmente atribuido al azar y que de manera involuntaria origina daños en las personas y los bienes, presentándose la imprevisibilidad como algo inherente al propio hecho que da origen a un resultado no querido ni buscado por su autor 6 . Pero la experiencia nos ha venido a demostrar que la imprevisibilidad o falta de intencionalidad puede venir acompañada de otros elementos como son la falta de diligencia debida por parte del conductor o la infracción de un deber objetivo de cuidado ${ }^{7}$. Es por ello que parte de los autores prefieran referirse actualmente a este tipo de hechos no como accidentes de tráfico sino como siniestros viales, pues la producción del resultado lesivo difícilmente encuentra encaje en la definición de accidente, hasta el punto que la concurrencia de determinados factores

4 Mingorance SÁnchez, José Antonio, "La seguridad vial en el ordenamiento penal: justificación y crítica”, Revista de Derecho UNED, n 20, 2017, pág. 429.

5 DiReCCIÓN GENERAL DE TRÁFICO, "Los accidentes de tráfico se cobran la vida de 870 personas durante el año pasado". Nota de prensa DGT 07 ENERO 2021. Recuperado el 4 de agosto de 2021 de https://www.dgt.es/es/prensa/notas-deprensa/2021/Los_accidentes_de_trafico_se_cobran_la_vida_de_870_personas_durante_el_ano_pasado.shtml

6 Dirección General de Tráfico, Cuestiones de seguridad - Edición 2019, pág. 16. Recuperado el 4 de agosto de 2021 de https://sede.dgt.gob.es/sede-estaticos/Galerias/permisos-de-conducir/certificacion-aptitud-profesores-formacionvial/2019/Manual-II-Cuestiones-de-Seguridad-Vial-2019.pdf

7 Sobre el particular, véase AgÜERo RAMÓN-Llin, ElENA, “¿Accidente de tráfico o violencia vial?”, en La reconstrucción de accidentes de tráfico. SIRAT 2014, edit. Juan F. Dols Ruiz, Universitat Politècnica de València, Valencia 2014, pág. 20. Recuperado el 4 de agosto de 2021 de http://hdl.handle.net/10251/46088. 
de riesgo en la dinámica comisiva (consumo de alcohol, velocidad, distracciones, etc.) ha propiciado que en los últimos años la sociedad empiece a hablar abiertamente de "violencia vial"8.

Esta realidad social que supone la accidentalidad y las inmediatas consecuencias que representan las incesantes cifras de víctimas en carretera, tiene su origen con la misma aparición del automóvil y su posterior desarrollo y expansión en el nuevo modelo de sociedad surgida de la primera mitad del siglo Xx y que BECK ha denominado "sociedad del riesgo".

Estos nuevos riesgos, a diferencia de los riesgos empresariales y profesionales del siglo XIX, ya no se limitarán a lugares o grupos determinados, sino que contienen una tendencia globalizadora influenciada por el modelo de desarrollo y los complejos procesos de modernización en el campo tecnológico, económico y social.

El ejemplo paradigmático fue el desastre nuclear de Chernóbil, producido el 26 de abril de 1986, y la consiguiente amenaza de contaminación radioactiva que no respetaba fronteras y que obligó a plantearse las nuevas amenazas producto de la modernidad. Otros ejemplos de riesgo para esta sociedad compleja son el uso de materiales nocivos en la construcción o la industria, las pandemias, la contaminación y su efecto invernadero, las graves catástrofes que pueden llegar a originar los accidentes industriales o del transporte, así como el funcionamiento de los mercados, que van a fomentar un sentimiento de amenaza en el ciudadano.

Paralelamente, esta concepción del modelo que representa la nueva sociedad ha tenido una gran repercusión en la Ciencia del Derecho penal, "apreciándose un menoscabo de los principios básicos del derecho penal liberal, en aras de la función preventiva frente a los nuevos peligros. Se habla en este sentido de un "Derecho penal del riesgo" 10 .

8 Término acuñado por la Ley Orgánica 15/2007, de 30 de noviembre, por la que se modifica la Ley Orgánica 10/1995 de 23 de noviembre, del Código Penal, en materia de seguridad vial, y que el legislador utiliza en su Preámbulo a la hora de referirse a determinadas conductas relacionadas con la seguridad vial que exceden de lo que se considera un riesgo tolerable, en especial en materia de "excesos de velocidad que se han de tener por peligrosos o de niveles de ingesta de alcohol que hayan de merecer la misma consideración".

9 Véase BECK, UlRICH, La sociedad del riesgo: hacia una nueva modernidad, Paidós, Barcelona 1998.

10 Cerezo Mir, José, "Los delitos de peligro abstracto en el ámbito del Derecho penal del riesgo”, Revista de Derecho Penal y Criminología, n 10, 2002, pág. 54. 
Actualmente está fuera de toda duda la importancia que esta transformación del discurso político-criminal ha experimentado, impulsado por una importante demanda social y una necesaria adaptación del Derecho penal a las nuevas realidades sociales.

Es cierto que al amparo de esta precisa adaptación del Derecho penal moderno, se observa en la política criminal española una fuerte influencia inspirada en las diferentes ideologías políticas, en la existencia de poderosos grupos de presión o en las movilizaciones sociales impulsadas por los distintos medios de comunicación, muchas veces con intereses partidistas, lo que inevitablemente contribuye a un alejamiento de la orientación teleológica que debe regir el sistema jurídico-penal. Emerge de este modo el inevitable debate sobre una posible politización del Derecho penal del riesgo que lo lleve a cotas inaceptables totalmente al margen de los límites y principios que deberían marcar su frontera. No obstante consideramos que este modelo resulta necesario para afrontar los nuevos retos, aunque se muestra a su vez evidente su sometimiento a la compatibilidad con los principios normativos básicos del derecho penal ${ }^{11}$.

Los nuevos procesos tecnológicos al igual que los nuevos usos sociales, como puede ser el tráfico rodado, van a multiplicar las situaciones de incertidumbre, impulsando una mayor demanda de intervención socioestatal dirigida precisamente al control de esas nuevas amenazas. Surge así un punto de conflicto en el que parece que se están abandonando las concepciones del Estado liberal clásico, con la aparición de un nuevo Derecho penal con una clara tendencia a la pragmatización en el marco de la actual sociedad, dando origen a lo que se ha venido en denominar el "riesgo permitido"12.

11 En este punto se coincide con Paredes Castañón, José Manuel, "El riesgo como construcción conceptual: sobre el uso y el abuso de las ciencias sociales en el discurso político-criminal del "derecho penal del riesgo»", Revista Catalana de Seguretat Pública, $\mathrm{n}^{\circ}$ 13, 2003, págs. 24-25; Crítico sin embargo con esta cuestión de la sociedad del riesgo y su influencia en la política criminal resulta ser DíEz RIPOLLÉs, José LuIs, "De la sociedad del riesgo a la seguridad ciudadana: un debate desenfocado", Revista Electrónica de Ciencia Penal y Criminología, no 7, 2005.

${ }_{12}$ Existe un debate falto de consenso sobre la interpretación del concepto "riesgo permitido", o socialmente adecuado, frente a situaciones o acciones que ponen en peligro determinados bienes jurídicos, lo que exige una ponderación político-criminal sobre la utilidad social de aquellas acciones peligrosas, que va a conducir a su permisión.

Se debe fijar por lo tanto el nivel máximo de amenaza que la sociedad considera asumible en el marco de su funcionamiento, equilibrando la relación costes y beneficios que representan determinadas actividades que, aun resultando útiles para el desarrollo social, llevan aparejada la puesta en peligro de bienes jurídicos, admitiendo con ello un cierto grado de inseguridad frente a la amenaza de paralizar una evolución y un desarrollo social necesario. Se trata por lo tanto de una 
Teniendo en cuenta que uno de los principales objetivos del Derecho penal es precisamente el de adaptarse a las nuevas sociedades desarrolladas contemporáneas, controlando las consecuencias perversas de ese desarrollo social y en especial los riesgos derivados de su desarrollo tecnológico y de la creciente complejidad de la estructura social, este nuevo Derecho penal se va a dotar de una estructura apoyada en dos pilares fundamentales como son: de una parte la figura de los delitos de peligro, en su doble vertiente de peligro concreto y abstracto; y de otra la creación de bienes jurídicos colectivos con una titularidad supraindividual.

Este modelo de Derecho penal pretende añadir al ya preexistente un nuevo catálogo de prohibiciones penales, anticipando de este modo la intervención penal mediante la técnica legislativa de los delitos de peligro, así como un elenco de bienes jurídicos que engloben las nuevas realidades sociales surgidas del proceso de modernización social ${ }^{13}$.

\section{TEORÍAS DOBRE LA MODERNIZACIÓN DEL DERECHO PENAL}

Sin pretender entrar en profundidad en el debate surgido en torno a la justificación o no de la modernización que la sociedad del riesgo ha impulsado en el Derecho penal, sí resulta de interés presentar estas dos posturas contrapuestas para que nos permitan así juzgar positiva o negativamente esta evolución.

El dilema que surge ante las respuestas que el ordenamiento jurídico va a adoptar frente a las nuevas amenazas, hacen surgir diversas posturas doctrinales que van a valorar esta necesidad o no de la expansión del Derecho penal, posturas que pueden agruparse alrededor de dos discursos ideológicos y político-criminales diferentes, unas en contra de la modernización del Derecho penal y otras a favor.

elección político-criminal basada en la determinación de aquellas situaciones que a pesar de ser creadoras de incertidumbre van a quedar cubiertas por un riesgo permitido que las excluye por ello de la imputación típica.

Este riesgo permitido se va a basar en el deber de cuidado exigido a quien realiza la acción peligrosa y se va a poner de manifiesto en el principio de confianza que debe primar entre todos los miembros del grupo social.

13 Paredes Castañón, J. M., op cit., págs. 12-13 


\section{II.1. Teorías de resistencia a la modernización del Derecho penal}

Actualmente podemos encontrar una parte de la doctrina que viene siendo crítica con este Derecho penal moderno, abogando por un Derecho penal mínimo reducido a lo que se consideran bienes jurídicos clásicos en torno a derechos básicos del individuo, así como un respeto a ultranza de las reglas de imputación y a los principios político-criminales de garantía del Derecho penal clásico de la Ilustración ${ }^{14}$.

Defensor a ultranza de esta postura es HASSEMER, máximo representante de la Escuela de Frankfurt, para quien el Derecho penal moderno se convierte en un medio de solución de conflictos similar a otros menos severos y que terminan por colocarlo como una ley blanda (soft law), convirtiéndolo en un recurso que no se diferencia de otros, en un Derecho Penal simbólico ${ }^{15}$. HASSEMER propone por ello la reducción del Código Penal a su núcleo mínimo sobre la base de la lesión a bienes jurídicos individuales tradicionales y casos de grave peligro, recogiendo el resto en un bloque aparte denominado "Derecho penal de intervención" de carácter extrapenal.

Otro autor que podría integrarse en este bloque es JAKOBS, aunque no resulta fácil encuadrarle entre las posturas favorables o contrarias, pues si bien existen rasgos compatibles con un Derecho penal moderno, también se pronuncia de forma bastante crítica frente a algunos aspectos del mismo, como en la anticipación de la tutela penal a través de la criminalización previa a la lesión del bien jurídico $^{16}$. A este autor se le atribuye la denominación de "Derecho penal del enemigo", en donde el sujeto peligroso (enemigo) se va a caracterizar por abandonar el Derecho de forma permanente, concibiéndose como una "fuente de peligro" a la que el Estado debe hacer

14 En este sentido Martínez-Buján PÉREz, Carlos, "Algunas reflexiones sobre la moderna teoría del big crunch en la selección de bienes jurídico-penales (especial referencia al ámbito económico)", Anuario da Facultade de Dereito da Universidade da Coruña, $\mathrm{n}^{\circ} 7,2003$, pág. 954.

$15 \mathrm{Al}$ respecto, véase HASSEMER, WiNDFRIED, "Rasgos y crisis del derecho penal moderno", Anuario de Derecho Penal y Ciencias Penales, vol. 45 n 1, 1992, págs. 238244; también HasSEMER, WindFrIED, "Derecho penal simbólico y protección de bienes jurídicos", Nuevo foro penal, no 51, 1991, pág. 30, "El Derecho penal simbólico se da bajo formas muy diversas: Derecho penal que está menos orientado a la protección del bien jurídico que a efectos políticos más amplios como la satisfacción de una «necesidad de acción

16 Al respecto, véase SOTOMAyor Acosta, JUAN OBERTo y RESTREPo Rodríguez, Diana MaRía, "El debate de la modernización del Derecho penal: Materiales de investigación”, Cuadernos de investigación, n 53, 2007, págs. 17-19. 
frente mediante su eliminación preventiva, en lo que algunos autores denominan críticamente como "Derecho penal de autor" en contraposición al "Derecho penal de hecho"17.

En esta misma línea se encuentran también los penalistas italianos BARATTA y FERRAJOLI, quienes sobre la idea de mínima intervención penal, apuestan igualmente por un Derecho penal mínimo en contraposición a un Derecho penal máximo que se identificaría con un Estado absoluto o totalitario. La idea de este Derecho penal máximo radica en la certeza de que ningún culpable resulte impune, a costa de que algún inocente pueda ser castigado, mientras que el Derecho penal mínimo persigue la certeza de que ningún inocente sea castigado, a costa de la incertidumbre de que algún culpable pueda resultar impune, lo que viene a estar garantizado por el principio in dubio pro reo ${ }^{18}$.

En España esta postura es defendida por Silva Sánchez, para quien el recurso al Derecho penal puede constituir una salida fácil a la que los poderes públicos van a recurrir para hacer frente a graves problemas sociales que no pueden o no quieren resolver por otros medios, optando por atender una demanda social de intervención punitiva sin base real ${ }^{19}$, en una política que algunos denominan como de "populismo punitivo". La introducción de nuevos objetos de protección junto a la anticipación de las fronteras de la protección penal ha motivado una rápida transición del modelo de delito de lesión de bienes jurídicos individuales al modelo de peligro para otros bienes supraindividuales ${ }^{20}$, lo que ha culminado en un Derecho penal "administrativizado", en un Derecho del daño cumulativo o, también, del daño derivado de la repetición ${ }^{21}$.

17 En este sentido Jakobs, Günther y Cancio Meliá, Manuel, Derecho penal del enemigo, Civitas, Madrid 2003, 29-35. Para JАKOBS es necesario distinguir entre un "Derecho penal del ciudadano" (que va a aplicar a quienes no organizan su vida en torno al delito, respecto de los cuales la pena busca la contradicción de un hecho parar asegurar la vigencia normativa), de un "Derecho penal del enemigo" (que se aplica a quienes organizan su vida en torno al delito, respecto de los cuales lo importante es la eliminación de un peligro).

18 Véase Baratta, Alessandro, Criminología y sistema penal (Compilacion in memoriam), B de F, Montevideo-Buenos Aires 2004; también FerRAJOLI, LuIGI, Derecho y Razón. Teoría del garantismo penal, Trotta, Madrid 1995.

19 Así lo entiende Silva Sánchez, Jesús María, La expansión del Derecho penal. Aspectos de la politica criminal en las sociedades postindustriales, Civitas Madrid, págs. 113.

20 Ibid., pág. 121

21 Para SiLva SÁNCHEZ, el Derecho administrativo sancionador es entendido como un sistema orientado a ordenar de modo general sectores de actividad, reforzando son sus sanciones el modelo de gestión sectorial, no estando por ello vinculado a criterios de lesividad o peligrosidad, operando con el "daño cumulativo" que 
Una postura intermedia entre las propuestas por HASSEMER y Silva SÁnchez la encontramos en MARTínez-BuJán, quien considera preferible la propuesta de un modelo dual del sistema penal regido por las mismas reglas de imputación y principios de garantía jurídico-penales, aunque estos últimos deban ser flexibilizados o relativizados, no contemplándose penas privativas de libertad para este Derecho penal moderno ${ }^{22}$.

\section{II.2. Teorías favorables a la modernización del Derecho penal}

Frente a las tendencias reduccionistas que defienden un Derecho penal mínimo o nuclear, basado en bienes jurídicos personales y tipos configurados como delitos de lesión, encontramos otras opuestas que abogan por una expansión o modernización del Derecho penal.

En esta línea se posiciona el alemán SchÜNEMANN, defensor indiscutible de esta teoría y crítico con la Escuela de Frankfurt, para quien la modernización de la criminalidad hace irrecusable la correspondiente modernización del Derecho penal, presentándose igualmente como característico de esta nueva sociedad del riesgo la sustitución de los contextos individuales por otros colectivos, reemplazando el contacto personal por otros comportamientos estandarizados y produciéndose con ello el tránsito desde el delito de resultado clásico hacia el moderno delito de peligro ${ }^{23}$.

En España uno de los defensores de esta línea con la cual nos identificamos es GRACIA MARTín, para quien la aparición de nuevos conflictos derivados de la evolución social no pueden ser actualmente afrontados ni resueltos por el Estado Liberal, debiendo el Derecho penal seguir el camino que vaya trazando la evolución social

exime de hecho de una valoración del hecho específico considerado aisladamente y conformándose como una ponderación del "peligro global", es decir del peligro estadístico derivado de la hipotética generalización de conductas como la descrita. El Derecho penal clásico no puede admitir la imputación de una conducta individual que no lesione ni ponga en peligro un bien jurídico, operando sólo con un efecto sumatorio o de peligro global que resulta de la eventual generalización de esa conducta (delitos de acumulación).

22 Martínez-Buján PÉrez, C., op.cit., pág. 964-965.

23 Véase SchünEmANn, BERnd, "Consideraciones críticas sobre la actuación espiritual de la ciencia jurídico-penal alemana", Anuario de Derecho Penal y Ciencias Penales, vol. 49 n ${ }^{\circ}$ 1, 1996, págs. 189-199. El autor admira la intuición del legislador al saber desarrollar sin dilación alguna, por parte del Derecho penal, los delitos de peligro abstracto, afirmando que no se trata de algo nuevo puesto que este grupo de delitos ya aparecían en las leyes penales de la época de la Ilustración. 
y el propio Estado ${ }^{24}$. Para este autor en la evolución de la sociedad pueden surgir bienes jurídicos que se deban subordinar a la realización de determinas actividades valoradas socialmente, a pesar de que produzcan o puedan producir el menoscabo de algún bien jurídico implicado. Aunque una acción considerada en principio socialmente adecuada podrá ser considerada inadecuada, cuando se produzca una inobservancia del cuidado objetivamente debido y con ello unas consecuencias previsibles que excedan de las normales que la acción socialmente adecuada pueda producir ${ }^{25}$.

Otra autora defensora de estas posturas con las que coincidimos es CORCOY BIDASOLO, quien opina que en el marco de la sociedad compleja surgida de la nueva sociedad del riesgo, van a aparecer una serie de interacciones interpersonales anónimas que obligarán a redefinir los intereses merecedores de tutela y con ello la necesidad de intervención penal para la prevención de nuevos riesgos ${ }^{26}$, no obstante, esta legitimidad de la intervención penal debe sujetarse a la permanente revisión de todas las figuras delictivas, debiendo operar los principios limitativos del ius puniendi en la totalidad del sistema penal $^{27}$.

Como apunta Cerezo Mir, actualmente "no es posible una vuelta al Derecho penal del siglo XIX, reduciendo básicamente el Derecho penal a la protección de los bienes jurídicos individuales". El Derecho penal debe evolucionar hacia el Estado de bienestar para evitar desconectarse del fin de conseguir una mayor justicia social ${ }^{28}$.

Nos guste o no, estamos asistiendo a un fenómeno que nos obliga a redefinir el moderno Derecho penal de acuerdo con las nuevas necesidades sociales, que impulsan una modernización y adaptación del Derecho penal al nuevo modelo de sociedad, muy diferente al modelo para el que fueron pensadas las bases del Derecho penal ilustrado o liberal. Esta nueva forma de control social formal debe

24 Sobre el particular, véase GRACIA MARTín, LuIs, "La modernización del Derecho penal como exigencia de la realización del postulado del Estado de Derecho (Social y Democrático)", Revista de Derecho Penal y Criminología, no 3, 2010, págs. 43-44.

25 En este sentido, véase Gracia Martín, Luis, "El finalismo como método sintético real-normativo para la construcción de la teoría del delito", Revista electrónica de Ciencia Penal y Criminología, no 6, 2004, págs. 20-21.

26 Corcoy Bidasolo, Mirentxu, "Exigibilidad en el ámbito del conocimiento y control de riesgos: teorización”, Revista Catalana de Seguretat Pública, no 13, 2003, pág. 33.

27 Corcoy Bidasolo, Mirentxu, "Legitimidad de la protección de bienes jurídico-penales supraindividuales”, Revista Cenipec, no 30, 2011, pág. 6.

28 De esta opinión es Cerezo Mir, J., op. cit., pág. 56. 
adaptarse a las nuevas características sociales, aunque esta adaptación se debe realizar sin perder su naturaleza instrumental de ultima ratio, pues de no ser así se correría el riesgo de convertirse en una herramienta completamente disfuncional o en un mecanismo puramente simbólico ${ }^{29}$.

De lo ya expuesto se puede concluir que la postura dominante y la que finalmente ha calado en los ordenamientos jurídicos de nuestro entorno es la de modernización del Derecho penal, adaptándolo a las nuevas realidades sociales y a las nuevas condiciones que van evolucionando diariamente, pues lo contrario supondría un Derecho penal totalmente desconectado de la realidad actual y anclado en una realidad pretérita sin sustento en las necesidades e intereses vitales actuales, que llegaría incluso a impedir el normal desarrollo social suponiendo un lastre a las nuevas iniciativas y logros tecnológicos e industriales.

Pero a la vez, esta necesidad de modernización tampoco puede efectuarse a espaldas de unos principios y garantías político-criminales que permitan servir de freno al propio aparato estatal en el establecimiento de las reglas de imputación de la responsabilidad penal.

\section{EL PELIGRO EN EL DERECHO PENAL DEL RIESGO}

El peligro se presenta como un concepto extrapenal de difícil determinación que obliga a recurrir a la doctrina para delimitarlo, siendo la postura mayoritaria la que lo concibe desde un punto de vista objetivo fundamentado en la posibilidad o probabilidad de un resultado lesivo que precisa conjuntamente de una previa situación peligrosa. Pero en esta concepción objetiva de peligro es preciso además establecer el grado de probabilidad mínimo exigido a través del denominado "juicio de peligro".

Del estudio de las diferentes posturas doctrinales sobre la materia podemos encontrar diversas definiciones de peligro, como por ejemplo: "el estado situacional que probablemente aboca a la lesión de un bien jurídico, siendo esta situación algo real y no un mero juicio de probabilidad" 30 .

29 Al respeto, véase Araque Moreno, Diego, “¿Derecho penal del riesgo o Derecho penal liberal?, Revista Cenipec, no 31, 2012, págs. 28-32.

30 BERISTÁIN IPIÑA, ANTONIO, Cuestiones penales y criminológicas, REUS, Madrid 1979, pág. 272. 
Para otros, por peligro debemos entender, en consonancia con la mayor parte de la doctrina, "la probabilidad - no en sentido matemático, sino en el de relevante posibilidad- de que se produzca la lesión del bien jurídico" ${ }^{31}$.

Además hay quienes, coincidiendo con esta concepción de peligro, añaden un segundo elemento para que se pueda configurar una situación como penalmente peligrosa ${ }^{32}: 1^{\circ}$.- la probabilidad o posibilidad de producción del resultado temido; y, $2^{\circ}$.- el carácter dañoso del resultado para uno de los bienes considerados dignos de protección jurídica ${ }^{33}$. Y aunque el segundo requisito no ha sido objeto de polémica en la doctrina, el primero ha venido planteando problemas tanto respecto al propio concepto como al grado de probabilidad o posibilidad.

Según esto, podríamos entender que la probabilidad de un resultado lesivo tendrá relevancia penal cuando el legislador considere que el grado de ésta convierte una acción concreta en suficientemente peligrosa para los bienes jurídicos protegidos, pudiéndose concluir que estaríamos ante diferentes grados de peligro en función de los diferentes grados de probabilidad. Constituye por lo tanto un problema de política criminal la determinación de cuál va a ser el grado de peligro necesario, capaz de identificar y sancionar una conducta como peligrosa.

Para CoRcoy BIDAsolo, autora a la que se atribuye una concepción normativa de peligro, éste es aquel que "se puede evaluar, en cuanto se puede y se debe conocer y que, en consecuencia, se puede y debe controlar" 34 , y esas amenazas surgidas de la nueva sociedad, que se van a poder conocer y por lo tanto controlar, son ahora denominados riesgos, cuyo control en atención a la idea de evitabilidad, por parte de quienes están obligados a ello, puede ser exigido por la sociedad $^{35}$.

31 Barbero Santos, Marino, "Contribución al estudio de los delitos de peligro abstracto”, Anuario de derecho penal y ciencias penales, vol. 26, 1973, pág. 492.

32 Al respecto, véase Gómez Pavón, Pilar, El delito de conducción bajo la influencia de bebidas alcohólicas, drogas tóxicas o estupefacientes y análisis del artículo 383 del Código Penal, Editorial Bosch, Barcelona 2015, págs. 106-107.

33 A idéntica conclusión llegan Madrigal NAVARRO, JAVIER, "Delitos de peligro abstracto, fundamento, crítica y configuración normativa”, Revista Judicial, $\mathrm{n}^{\circ} 115$, 2015, pág. 172; Terradillos Basoco, JuAn, "Peligro abstracto y garantías penales", Nuevo Foro Penal, no 62, 1999, pág. 69; Corigliano, Mario Eduardo, "Delitos de peligro. Hacia una definición político-criminal y sistemática. La frontera de lo punible en el Derecho Penal", Revista internauta de práctica jurídica, n ${ }^{\circ} 18,2006$, págs. 1-2.

34 Corcoy Bidasolo, M. (2011), op. cit., pág. 6.

35 Corcoy Bidasolo, M. (2003), op. cit., págs. 40-41. 
Para la precitada autora, el concepto válido de peligro para el Derecho penal es aquel que trata de poner en relación el peligro objetivo real con el peligro aparente ex ante, pudiendo solo ser calificado como riesgo cuando tenga una relevancia penal. Por ello solo podrá llevarse a cabo una imputación objetiva de un resultado de peligro o lesión de un bien jurídico-penal, cuando esa probabilidad se corresponda con una situación muy próxima a la afectación real del bien. Debiendo igualmente considerar otras variables, como son: $1^{\mathrm{a}}$.- la entidad del bien jurídico protegido; y, $2^{\mathrm{a}}$.- la ponderación de la utilidad social de la actividad desarrollada.

En consecuencia se podrá calificar una conducta como peligrosa cuando se verifique la probabilidad de lesión en el caso concreto, atendiendo a los bienes potencialmente puestos en peligro y al ámbito de actividad donde se desarrolla la acción, y aquí el concepto de probabilidad debe ser entendido como una noción lógica que sirva para sostener un reproche penal.

\section{III.1. El juicio de peligro y su incursión en el Derecho penal del tráfico}

En base a la peligrosidad el legislador va a tipificar todas aquellas conductas que superen un nivel de riesgo que se considere no permitido por la sociedad, procediendo posteriormente a valorarla como peligrosa, recurriendo para ello a un juicio desarrollado a posteriori. Pero como afirma la doctrina mayoritaria, este juicio que se efectúa ex post debe tener una referencia ex ante, es decir, en el momento en que se realiza la acción.

Este juicio de peligro coincide con un juicio de previsibilidad objetiva que debe ser efectuado ex ante, pues si se realiza ex post y el resultado no se llega a materializar es porque no concurrían las condiciones necesarias y se debería concluir que la acción no habría sido peligrosa. Y este juicio debe realizarse por una persona inteligente, colocándose en la posición del autor al comienzo de la acción y teniendo en cuenta todas las circunstancias cognoscibles, así como las que eran conocidas por el autor en el momento de ejecutar la acción, más la experiencia común de la época ${ }^{36}$.

El peligro se convierte así en una cualidad de la conducta que la transforma en peligrosa, diferenciándola de la consecuencia que va

36 Cerezo Mir, J., op. cit., pág. 49; también Madrigal Navarro, J., op. cit., pág. 176. 
a ser el resultado de peligro para el bien jurídico protegido. Aquí la postura mayoritaria considera que la antijuridicidad de estas conductas típicas debe incluir tanto el desvalor de la acción como el del resultado (tesis dualista de lo injusto), que admite la punición en base a su peligrosidad y a la afectación del bien jurídico ${ }^{37}$.

Queda de este modo delimitado qué debe entenderse por "riesgo penalmente relevante", pudiendo quedar aquí englobadas tanto las acciones dolosas como las imprudentes, es decir, tanto los riesgos conocidos por el sujeto como los no conocidos pero que tenía la obligación de conocer, aunque quedando estos últimos limitados a aquellos supuestos de imprudencia grave desde una perspectiva político-criminal, en donde el grado de conocimiento penalmente exigido al autor no debería ser un conocimiento científico y exacto. Este conocimiento se circunscribiría así a la esfera del profano, siendo por ello suficiente conocer que una determinada conducta puede provocar un resultado lesivo así como que existe la posibilidad de controlar dicho riesgo ${ }^{38}$.

Se puede concluir que el peligro, desde el punto de vista normativo, radica en un juicio de previsibilidad de que un determinado bien resulte afectado por un comportamiento, sin que llegue a producir efectivamente la lesión del mismo, y este juicio de peligro debe efectuarse ex ante, colocándose para ello el Juez en el momento en que se realizó la acción y decidiendo sobre la existencia de posibilidad o probabilidad de producir un daño futuro.

Pero esta acción también va a poder ser realizada por el legislador que la va a plasmar en tipos penales específicos, evitando de este modo un protagonismo demasiado elevado del Juez que daría lugar a la inseguridad jurídica que provocaría el exceso de subjetivismo.

Este resulta ser uno de los motivos que ha impulsado la introducción de modificaciones en el Capítulo IV del Título XVII del Código Penal, dedicado a los delitos contra la seguridad vial, mediante la LO 15/2007, con nuevas incriminaciones junto a la ampliación o remodelación de otros tipos penales; o la última reforma introducida por la LO 2/2019 que incorpora el delito de abandono del lugar del accidente por parte del causante del mismo, con una redacción

37 Véanse Corcoy Bidasolo, M. (2011), op. cit., pág. 13; también Maldonado FuENTES, Francisco, "Reflexiones sobre las técnicas de tipificación de los llamados delitos de peligro en el moderno derecho penal", Revista de estudios de la justicia, $\mathrm{n}^{\circ} 7,2006$, pág. 59 .

38 Se coincide en esta opinión con Corcoy Bidasolo, M., (2003), op. cit., págs. 39-40. 
autónoma respecto del artículo 195.3 CP. Y todo ello motivado por las difícilmente comprensibles resoluciones judiciales, en especial las relacionadas con el consumo de alcohol y los excesos de velocidad, que creaban una gran repulsa social por su excesiva benevolencia ante hechos extremadamente graves en donde el autor actuaba con la más absoluta indiferencia. Destacar aquí también los trágicos atropellos de ciclistas que en algunos casos quedaban impunes, o el controvertido caso "Farruquito" en 2003, donde tras un atropello mortal por imprudencia grave y omisión de socorro, al conductor le fue impuesta una pena mínima de 16 meses de prisión.

Son precisamente estas reformas penales las que han vuelto a avivar las críticas que ya venía planteando la doctrina acerca de esa expansión del Derecho penal, de esa administrativación de un Derecho penal que tipifica nuevas conductas movido por una fuerte demanda social, conductas muchas de ellas que ya venían siendo castigadas en el correspondiente Derecho administrativo sancionador y recogidas en el Real Decreto Legislativo 6/2015, de 30 de octubre, por el que se aprueba el actual texto refundido de la Ley sobre Tráfico, Circulación de Vehículos a Motor y Seguridad Vial.

Resulta ser además en este ámbito de la seguridad vial en donde se han venido produciendo los impulsos legislativos más relevantes en el marco de la sociedad del riesgo surgida a mediados de siglo Xx, haciendo aflorar nuevos aspectos penales de la circulación rodada así como su tratamiento preventivo y punitivo en la Comisión General de Codificación que dio pie a la aprobación de la primera norma penal en este terreno, una ley especial, la "Ley del Automóvil" de 9 de Mayo de 1950, calificada por algunos como acertada respecto a la elección de las fórmulas legislativas más adecuadas para satisfacer las necesidades de la prevención penal, sin incurrir en los fáciles excesos del dogmatismo o la inexorabilidad punitiva.

Se produjo así una evolución desde la imprudencia punible hasta las nuevas tipologías de peligro, que pretendía con la Ley del Automóvil no solo la represión de conductas de peligro, antes prácticamente impunes, sino que además se trataba de complementar el tratamiento jurídico de la culpa. De este modo se pasaría a definir un conjunto de delitos de peligro ante hechos atentatorios para la seguridad del tráfico que hasta ese momento constituían simples infracciones administrativas.

El objeto de esta nueva ley especial sería penalizar aquellas conductas cuya gravedad traspasara el contenido esencial de "riesgo 
socialmente tolerable", castigando tan solo los hechos que encerraran un peligro grave para la seguridad colectiva, persistiendo el carácter administrativo de la sanción en la mayor parte de las infracciones del tráfico, no perdiendo la pena su contenido axiológico.

La selección de estas primeras conductas creadoras de un grave riesgo social se habría hecho sobre las actitudes del tráfico que encerraban un peligro capaz de perturbar gravemente el sentimiento de seguridad pública. Será por ello la intolerancia social hacia la ejecución peligrosa de una acción, que de ser realizada normalmente sería aceptada, la que determinará el criterio en que se asentará su reproche penal ${ }^{39}$.

La evolución normativa expuesta pretende fijar la atención en el instante en que la misma peligrosidad concreta de la acción crea la probabilidad de la producción de un daño a un bien merecedor de protección, rompiendo de este modo con el tratamiento jurídico tradicional que ante hechos ilícitos con arranque culposo o negligente exigía un posterior resultado material lesivo de un bien jurídico para poder ser castigado.

Nacen de este modo en el ámbito de la seguridad vial los denominados delitos de peligro concreto, que irán ampliando su protección incluso a situaciones en donde ya no se exija esa específica amenaza para el bien jurídico. Pero esta inexorable ampliación, que va a dar lugar a nuevos injustos calificados como de peligro abstracto y que serán abordados en el siguiente punto, ha comenzado a invadir este apartado del Código Penal.

39 Sobre el particular Conde-PumPido Ferreiro, CÁNDIDo, "Don Eugenio Cuello Calón y los delitos de tráfico", Anuario de Derecho Penal y Ciencias Penales, vol. 16, 1963, págs. 531-542. Para este autor, en esa época los posibles riesgos derivados de actos culposos eran muy remotos y representaban una escasa trascendencia social que se plasmaba en la inexistencia de una amenaza percibida por la sociedad, algo que iría cambiando a medida que el automóvil tomaba protagonismo y que comenzó a trasladar a la sociedad la existencia de un peligro latente hacia estas acciones peligrosas pero a la vez socialmente tolerables. El individuo ya no se sentía protegido por las sanciones que recibían estos hechos culposos exigiendo nuevas medidas tendentes a minimizar los posibles daños que estas acciones generaban, pero ahora desde el propio inicio de la ejecución de la acción.

La delincuencia dolosa, que venía representando la primacía en la esencia penal, se estaba viendo igualada o incluso superada por la delincuencia culposa, y en este sentido los datos aportados revelan que en 1953, de 23.666 sentencias condenatorias 1.288 correspondían a delitos por imprudencia y 253 a delitos recogidos en la Ley del Automóvil de 1950, mientras que en 1959 de 20.995 sentencias 3.174 se correspondían a delitos imprudentes y 2.594 a delitos de la Ley de 1950. 


\section{LOS DELITOS DE PELIGRO EN LA SOCIEDAD DEL RIESGO}

Los nuevos delitos de peligro se van a diferenciar de los delitos de lesión en base a la intensidad del ataque que se realiza al bien jurídico, que representa los "valores ideales del orden social", constituyendo este ataque un desprecio a ese valor ideal que resultaría de menor intensidad en esta tipología de injustos, frente a los delitos de lesión en los que se evidenciaría un resultado material sobre el objeto de la acción ${ }^{40}$.

Dentro de esta categoría cabe efectuar la clásica distinción admitida por la doctrina mayoritaria entre delitos de peligro concreto $\mathrm{y}$ delitos de peligro abstracto atendiendo a la intensidad de la amenaza sobre bien jurídico. Y este tipo de ilícitos "solo van a poder clasificarse de esta forma si se ponen en relación con otros en los que el bien jurídico penal protegido sea individual, concibiéndolos así como adelantamientos de la barrera de protección" ${ }^{41}$.

Desde la perspectiva material, en estos delitos se va a atribuir la responsabilidad penal a título doloso ${ }^{42}$ a quien conocía los riesgos, aun en la esfera del profano, y toma la decisión de continuar con la realización de la acción peligrosa (elemento cognitivo); a lo que se uniría la constatación de la decisión por parte del autor de continuar con esta acción en contra del bien jurídico o a favor del injusto (elemento volitivo) ${ }^{43}$, lo que se traduce en ese mayor desvalor de la acción que presenta el dolo frente a la imprudencia. Este desvalor del resultado que el sujeto puede o no aceptar se va a materializar precisamente en la constatación de una decisión en contra del bien jurídico ${ }^{44}$.

40 Véase Gómez Pavón, P., op. cit., págs. 113-114.

41 Se coincide aquí con Corcoy Bidasolo, M. (2011), op. cit., pág. 6.

42 Para un sector importante de la doctrina así como jurisprudencial, toda participación en los delitos imprudentes sería considerada impune, permitiéndose solo castigar la autoría en sentido estricto, aunque otro sector doctrinal se posiciona en contra de esta corriente. Véase FEIJóo SÁNCHEZ, BERNARDO, "La participación imprudente y la participación en el delito imprudente en el Derecho penal español", Revista Internacional de Derecho Penal Contemporáneo", n 4, 2003, págs. 1-4.

43 Véase Tribunal Supremo (Sala de la Penal). Sentencia núm. 902/2010 de 30 de enero, fundamento jurídico $3^{\circ}$. Pare este Tribunal el concepto de dolo normativo se basa en el conocimiento de que la conducta que se realiza pone en concreto peligro el bien jurídico protegido. En el conocimiento del riesgo se encuentra implícito el conocimiento del resultado y desde luego la decisión del autor está vinculada al mismo, asumiendo, aceptando o conformándose con él, o que cuanto menos le resulta indiferente el resultado que probablemente va a generar su conducta. A este elemento volitivo la doctrina le viene asignando los nombres de asentimiento, asunción, conformidad y aceptación; también Corigliano, M. E., op. cit., pág. 9.

44 Véanse García, Esther Hava, "Dolo eventual y culpa consciente: criterios diferenciadores”, 2003, págs. 19-20. Recuperado el 4 de agosto de 2021 de http://perso. 
En estos ilícitos la idea del riesgo va a cobrar una especial relevancia dentro de la teoría de la imputación objetiva, de tal forma que en los delito de acción, como son todos los relacionados con la seguridad vial, se va a requerir necesariamente: $1^{\circ}$.- que el resultado haya sido causado por la conducta (relación de causalidad); y, $2^{\circ}$.la exigencia de una efectiva relación de riesgo entre el resultado y la conducta peligrosa, para poder fundamentar la autoría sobre la base de la restricción teleológica de los tipos penales ${ }^{45}$.

La fundamentación dogmática de ésta teoría se encuentra en: $1^{\circ}$.- la exclusión de los resultados imprevistos; $2^{\circ}$.- la exclusión igualmente de las situaciones que aun siendo peligrosas, están cubiertas por el riesgo permitido ${ }^{46} ; 3^{\circ}$.- la inobservancia de la diligencia debida resulta ser un elemento del injusto típico; y, $4^{\circ}$.- además de esta inobservancia y de la causación del resultado, éste último debe ser uno de los que la norma quiere impedir ${ }^{47}$.

En este sentido se puede observar una evolución tanto de la jurisprudencia como de la doctrina en el campo de la seguridad vial, comenzando por la interpretación que el Tribunal Supremo (TS) aplicaría en las primeras Sentencias tras la entrada en vigor de la Ley del Automóvil de 1950, prescindiendo totalmente del peligro como elemento normativo del tipo para tratar únicamente del daño lesivo producido y del grado de imprudencia. Otras Sentencias de este mismo Tribunal, como la de 15 de junio de 1955, la de 29 de noviembre de 1960 o la de abril de 1963, comenzarán a concebir el peligro como elemento básico de la imprudencia temeraria y a distinguir ya entre el peligro concreto y abstracto ${ }^{48}$.

unifr.ch/derechopenal/anuario/numeros\#2003; también CEREzo MIR, J., op. cit., págs. 63-65.

45 De esta opinión es Mir Puig, Santiago, Derecho Penal Parte General, Editorial Reppertor, Barcelona 2016, págs. 246-247, para el que la relación de causalidad no es el único elemento relevante para la imputación objetiva de un resultado, siendo necesaria pero no suficiente en los delitos de acción, pues requiere además un riesgo suficiente en la conducta que resulte adecuado a la gravedad del resultado.

${ }_{46}$ Mir Puig, S., op. cit., pág. 262, se trataría de riesgos propios de un tipo de actividad en sí misma adecuada socialmente en donde la utilidad social típica del sector de actividad impediría considerarla "típicamente relevante".

47 Mir Puig, SANTiago, "Significado y alcance de la imputación objetiva en Derecho penal”, Revista Electrónica de Ciencia Penal y Criminología, n 5, 2003, pág. 4, quien pone de manifiesto la exigencia de requerir tres niveles de imputación (juicio de atribución efectuado por el hombre) en el principio de culpabilidad y que se consideran necesarios para la completa imputación a un autor culpable: la imputación objetiva, la imputación subjetiva y la imputación individual o personal.

48 Al respecto, véase BERISTÁIN IPIÑA, A., op. cit., págs. 304-306. 
Más recientemente se ha vuelto a ratificar el TS en relación con los delitos de peligro abstracto - en los que ha de concurrir siempre un peligro real, aunque genérico o abstracto, pero no presunto- al exigir que en ellos debe observarse siempre una acción peligrosa ex ante (desvalor de la acción) que haga posible un contacto con el bien jurídico tutelado por la norma (desvalor potencial del resultado) ${ }^{49}$.

\section{IV.1. Los delitos de peligro concreto}

El paradigma de este tipo de delitos en el ámbito de la seguridad vial lo constituye el recogido en el artículo $380 \mathrm{CP}$, en donde se exige expresamente una puesta en concreto peligro para la vida o integridad de las personas, requiriéndose por lo tanto una constatación de que el bien jurídico se colocó en una situación de peligro próxima a la lesión a través de un análisis ex post.

Según esto, los delitos de peligro concreto no van a exigir la efectiva producción del resultado material para que pueda ser considerado como típico el comportamiento, bastando por ello solo con constatar el peligro creado para el bien jurídico protegido, en contraposición a los delitos de peligro abstracto donde el peligro, aun siendo real, no precisa esta constatación ${ }^{50}$.

Para CEREzo MIR, se podría considerar contraproducente la catalogación de determinadas conductas peligrosas como simples infracciones administrativas, dejando en manos del azar la posibilidad de exigir responsabilidad penal cuando se produzca el resultado lesivo, representando la pena la simple confirmación de la mala suerte del conductor y no una expresión del reproche ético-social. Y es en esta línea de reducción de la influencia del azar en la determinación de la responsabilidad penal por lo que se han insertado los delitos de peligro concreto entre las infracciones administrativas y los delitos culposos de resultado material ${ }^{51}$.

Resumiendo, se puede afirmar que en los delitos de peligro concreto, como es el caso de los tipos recogidos en los artículos 380 y

49 Tribunal Supremo (Sala de lo Penal, Sección $1^{\text {a }}$ ), Sentencia núm. 419/2017 de 8 de junio, fundamento jurídico 2.

50 Al respecto, véanse Gómez Pavón, P., op. cit., pág. 115; TerRadillos Basoco, J., cp. cit., págs. 72-73; Maldonado Fuentes, F., op. cit., pág. 33; Beristáin IPIÑA, A., op. cit., pág. 277.

51 Cerezo Mir, José, "Problemas fundamentales de los delitos contra la seguridad del tráfico”, Anuario de Derecho Penal y Ciencias Penales, vol. 23 n 3, 1970, pág. 595. 
$381 \mathrm{CP}^{52}$, se va a requerir en primer lugar la referencia expresa al peligro en la descripción del tipo y en segundo lugar la necesaria constatación por parte del Juez de su existencia real para el bien jurídico protegido. Dos son pues los componentes de estos delitos: una acción peligrosa y un resultado de peligro ${ }^{53}$.

\section{IV.2. Los delitos de peligro abstracto}

Representan la técnica legislativa que se interpone como una barrera más avanzada de protección penal con una muy difícil justificación jurídica y que ha ofrecido uno de los debates más intensos de la doctrina.

Para algunos se tratan de unas presunciones iuris et de iure de peligro, para otros se trata de delitos presuntos o delitos de mera desobediencia ante la ausencia del elemento típico que supone el peligro, hay también quienes prefieren denominarlos delitos de peligro potencial, hipotético o incluso delitos de acumulación, ante la opción del legislador de castigar penalmente determinadas conductas por considerarlas peligrosas en base a una valoración estadística o porque su reiteración resultaría peligrosa.

Aunque resulta difícil encontrar una justificación e incluso una denominación para este tipo de delitos, lo que sí se puede afirmar

52 Artículo $380 \mathrm{CP}$

El que condujere un vehículo a motor o un ciclomotor con temeridad manifiesta y pusiere en concreto peligro la vida o la integridad de las personas será castigado con las penas de prisión de seis meses a dos años y privación del derecho a conducir vehículos a motor y ciclomotores por tiempo superior a uno y hasta seis años.

A los efectos del presente precepto se reputará manifiestamente temeraria la conducción en la que concurrieren las circunstancias previstas en el apartado primero y en el inciso segundo del artículo anterior.

Artículo $381 \mathrm{CP}$

1.- Será castigado con las penas de prisión de dos a cinco años, multa de doce a veinticuatro meses y privación del derecho a conducir vehículos a motor y ciclomotores durante un periodo de seis a diez años el que, con manifiesto desprecio por la vida de los demás, realizare la conducta descrita en el artículo anterior.

2. Cuando no se hubiere puesto en concreto peligro la vida o la integridad de las personas, las penas serán de prisión de uno a dos años, multa de seis a doce meses y privación del derecho a conducir vehículos y ciclomotores por el tiempo previsto en el párrafo anterior.

53 Sobre el particular Fernández Bermejo, Daniel y Romero Jaime, Diego Jesús, "El delito de conducción manifiestamente temeraria. Algunas propuestas de mejora", Revista Aranzadi Doctrinal, no 1, 2017, pág. 5. Según estos autores "en relación con el resultado, el delito de peligro concreto requiere: a) un juicio de probabilidad cercana de lesión; b) el ingreso de un bien jurídico en el ámbito de influencia de una fuente de peligro; y, c) que dependa de la causalidad si se produce o no la lesión". 
es que estos encuentran su fundamento en la peligrosidad de la conducta y por lo tanto deberíamos apartar ya algunas concepciones como la mera violación formal de una norma (delitos formales o de mera desobediencia) o la exclusiva peligrosidad estadística.

Como ya se ha expuesto antes, la antijuridicidad de este tipo de injustos habría que ubicarla por un lado en el desvalor social de la acción determinado ex ante (voluntariedad y conciencia de la acción), al que le seguiría un desvalor social del resultado determinado ex post que se traduce en una afectación del bien jurídico protegido (antijuridicidad material) ${ }^{54}$, y es precisamente aquí donde surge la inevitable pregunta sobre la fundamentación del desvalor en estos delitos de peligro desde un punto de vista ex post.

Ante este conflicto podemos encontrar diversos modelos que pretenden fundamentar los delitos de peligro abstracto, pero ninguno de ellos logra responder adecuadamente a todas las cuestiones planteadas, siendo las tesis que se apoyan en el desvalor de la acción las que más se consiguen acercar a una posible fundamentación jurídica, todo ello en base a que la idoneidad de la acción para producir un resultado lesivo produce un injusto de peligrosidad ${ }^{55}$.

En los delitos de peligro abstracto los indicios de peligrosidad vienen fijados por la Ley en base a un comportamiento capaz de amenazar un bien jurídico, siendo por ello idóneo para ponerlo en peligro, consumándose la conducta por la mera ejecución de la acción. Según esto debería ser excluida toda conducta en la que se pueda demostrar que la acción jamás pudo suponer un peligro ${ }^{56}$. Y éste no resulta ser un elemento del tipo, como ocurre en los delitos

54 Véase Bustos Ramírez, Juan J. y Hormazábal Malarée, Hernán, Lecciones de Derecho Penal (volumen I). Fundamentos del sistema penal, esquema de la teoría del delito y del sujeto responsable y teoría de la determinación de la pena, Editorial Trotta, Madrid 1997, págs. 145-146.

55 En este sentido Cuesta Pastor, Pablo, El delito de conducción bajo la influencia de bebidas alcohólicas y el sistema de sanción por puntos de la Ley 17/2005, de 19 de junio, Dykinson, Madrid 2012, págs. 35-36; también Mendoza Buergo, Blanca, "La configuración del injusto (objetivo) de los delitos de peligro abstracto",

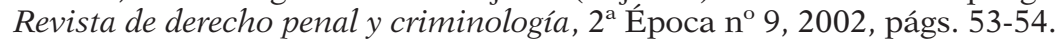

56 Al respecto, véanse Gómez Pavón, P., op. cit., págs. 116-117; Madrigal NAVARro, J., op. cit., pág. 171; Terradillos BASOco, J., op. cit., págs. 75-76; también Mendoza Buergo, B., op. cit., pág. 75; En este sentido véase Martínez-Buján Pérez, Carlos, Derecho penal económico. Parte general, Tirant lo Blanch, Valencia 1998, pág. 110, entiende que la idoneidad lesiva para el bien jurídico se presenta como un elemento valorativo inexcusable del tipo del injusto, considerando que si el autor adoptó previamente las medidas necesarias para evitar toda posibilidad de que el efectivo peligro se produjera, quedaría excluida la tipicidad. 
de peligro concreto, sino únicamente la ratio legis, es decir, el motivo que condujo al legislador a crear la figura delictiva ${ }^{57}$.

El rechazo y las críticas a los delitos de peligro abstracto puros se circunscriben a la falta real de perjuicio para un bien jurídico-penal, convirtiendo una de las principales ventajas político-criminales de estos ilícitos en su principal obstáculo ${ }^{58}$. De este modo, si bien actualmente la mayoría de las tesis que reconocen contenido material a estos delitos lo hacen desde el desvalor de la acción, también se observa cierta dificultad para asignar tal materialidad a un desvalor de resultado debido especialmente a la conservación del paradigma de lesión ${ }^{59}$.

Es por ello que la doctrina viene justificando este desvalor potencial de resultado desde el propio desvalor de la acción en base en un doble juicio sobre la peligrosidad que confirme la existencia de peligrosidad real en este tipo de delitos. Y desde esta peligrosidad de la acción se llega a una situación de peligro hacia el objeto de protección a través de acciones que ya no son dominables por el sujeto, que escapan a su control o gobierno, o que salen de su ámbito de dominio, entendiendo algunos autores que se produce con ello una real afectación del bien jurídico-penal como resultado jurídico, como concepto diferente del resultado material-formal ${ }^{60}$.

Va a ser dentro de esta tipología delictiva donde se enmarquen la mayoría de los delitos contra la seguridad vial, entendiendo el legislador que algunas conductas al volante sobrepasan el riesgo socialmente permitido y por lo tanto merecen reproche penal cuando el conductor, o cualquier otra persona como es el caso del artículo

57 Véanse Barbero Santos, M., op. cit., pág. 489; Cerezo Mir, J. (2002), op. cit., pág. 63, quien opina que desde el punto de vista de la legalidad, los delitos de peligro abstracto resultan ser más satisfactorios que los delitos imprudentes de resultado, donde la conducta prohibida no se encuentra descrita en el tipo, debiendo ser el Juez quien a posteriori la fije al determinar cuál debía haber sido el cuidado objetivamente debido.

Esta parece haber sido la línea seguida por el legislador en la aprobación de la Ley Orgánica 2/2019, de 1 de marzo, de modificación de la Ley Orgánica 10/1995, de 23 de noviembre, del Código Penal, en materia de imprudencia en la conducción de vehículos a motor o ciclomotor y sanción del abandono del lugar del accidente, al determinar de manera expresa qué tipo de conductas se considerarán imprudencia grave en los casos de homicidio imprudente.

58 De esta opinión Vargas Pinto, Tatiana, Delitos de peligro abstracto y resultado. Determinación de la incertidumbre penalmente relevante, Editorial Aranzadi, Cizur Menor 2007, pág. 325.

59 Ibid., pág. 348.

$60 \quad$ Ibid., págs. 339-346. 
$385 \mathrm{CP}^{61}$, realizan una acción considerada peligrosa y la misma sobrepasa las previsiones de control o dominio atribuidas al que la ejecuta, invadiendo por lo tanto la esfera de tranquilidad y seguridad en que el resto de ciudadanos se desenvuelven, es decir, colocando los bienes jurídicos vida e integridad bajo el peligro de lesión, una situación de peligro que el que ejecuta la acción no va a poder evitar y que el que la experimenta no tiene el deber de soportar.

Como ejemplo de delitos de peligro abstracto se suele hacer alusión a las conductas descritas en el artículo $379 \mathrm{CP}$, referidas a la velocidad excesiva o al consumo de alcohol o drogas en la conducción, que, aunque con alguna crítica a la técnica utilizada por el legislador, encontrarían justificación desde el punto de vista jurídico-penal. Un análisis más profundo del apartado dedicado a la tasa objetiva punible de alcohol permitiría incluso justificar el reproche penal en el caso del consumo combinado de alcohol y drogas por parte del conductor, debido al efecto multiplicador que producen estas últimas sobre tasas de alcohol incluso inferiores a la establecida penalmente, todo ello en base a las evidencias científicas ya conocidas. Aunque esta propuesta sería objeto de otro estudio que excede del presente trabajo.

No obstante, otros tipos penales también recogidos entre los delitos contra la seguridad vial encontrarían una más difícil justificación, como sería el caso de la negativa a someterse a las pruebas legalmente establecidas (art. $383 \mathrm{CP}$ ) o la conducción sin permiso o licencia (art. $384 \mathrm{CP})^{62}$, en donde resulta prácticamente imposible observar un desvalor del resultado, es decir, una afectación del bien jurídico seguridad vial, por el mero hecho de negarse a someterse a una prueba pericial sin más, o por carecer o haber perdido la vigencia de una autorización administrativa, por mucho que el legislador pretenda atribuir peligrosidad a estas conductas, es decir, un desvalor de la acción, configurando de este modo lo que parecen ser más unos tipos penales meramente formales.

\section{APROXIMACIÓN AL BIEN JURÍDICO PROTEGIDO}

La necesaria determinación del objeto de tutela constituye uno de los elementos esenciales en las limitaciones al ius puniendi del Estado y es a la vez la que sirve para deslindar la nueva formulación

61 En este artículo se castiga a todo aquel que originare un grave riesgo para la circulación realizando determinados actos.

62 Al respecto, véase Mingorance SÁnchez, José A., op. cit., págs. 448-449. 
penal de los delitos de peligro respecto de los ilegítimos delitos formales, es decir, las infracciones que no son susceptibles ni siquiera de ponerlo en peligro.

En el Derecho penal español el bien jurídico se encuentra en el núcleo de toda la teoría del delito, pudiendo encontrar diferentes posturas doctrinales que sirven de apoyo a su concepción y configuración.

Si bien todos los bienes jurídicos van a derivar finalmente de derechos subjetivos personales más amplios, definidos como la facultad jurídica reconocida a toda persona para exigir un comportamiento determinado, ambos conceptos no deben ser confundidos, pues el bien jurídico se va a identificar con un interés vital para el desarrollo del individuo en la sociedad, que debe ser valorado positivamente por el ordenamiento jurídico.

La búsqueda del contenido del bien jurídico surge como una consecuencia de los intentos por limitar el incontrolable avance del Derecho penal, cumpliendo así una función legitimadora y limitadora de la intervención punitiva del Estado, siendo esta exclusiva protección de los bienes jurídicos uno de los principios que rigen el Derecho penal, y presentándose por ello como básico el principio de lesividad.

Para la opinión mayoritaria actual la antijuridicidad de una conducta no solo debe ser formal, contraria a una norma jurídica, sino que precisa también de una antijuridicidad material, es decir, la producción de un riesgo o lesión hacia un objeto jurídico de protección que recibirá la denominación de bien jurídico.

Existe no obstante cierta dificultad para encontrar una definición uniforme que se refiera al concepto de bien jurídico así como respecto a su contenido, siendo identificado por algunos como el "interés vital para el desarrollo de los individuos de una sociedad determinada, que adquiere conocimiento jurídico"63, como una necesidad humana que determina una necesidad de protección. Con el concepto de bien jurídico lo que se pretende es designar el objeto protegido por el sistema penal, teniendo éste su origen en la base social, por lo que se comprende que estén en continua rediscusión y gocen de un carácter dinámico que permita tanto crear nuevos bienes como eliminar otros ${ }^{64}$.

63 Véase Kierszenbaum, Mariano, "El bien jurídico en el derecho penal. Algunas nociones básicas desde la óptica de la discusión actual”, Lecciones y Ensayos, ${ }^{\circ}$ 86, 2009, 188-189.

64 Bustos Ramírez, J. y Hormazábal Malarée, H., op. cit., págs. 57-59. 
De ese modo se puede entender que el concepto de bien jurídico tenga un significado genérico que lo relacione con todo aquello que tenga o pueda tener un valor o un interés para el grupo social en un momento histórico determinado. Su definición por ello surge de la propia relación social basada en la obligación de satisfacer las necesidades de cada miembro de la sociedad o de un colectivo, todo ello en beneficio del funcionamiento del sistema social ${ }^{65}$. Y estos bienes o intereses necesitados de protección jurídica muestran de una forma u otra una clara conexión con la realidad social ${ }^{66}$ y con juicios de valor que van a seleccionar aquellas realidades que se consideran merecedoras de protección ${ }^{67}$.

Las diferentes tendencias que pretenden dotar de contenido material al concepto de bien jurídico se pueden agrupar entre las que se fundamentan en torno al concepto de "dañosidad o perjuicio social", recurriendo a criterios sociológicos sobre la base de que protegiendo bienes jurídicos se van a proteger también las condiciones de convivencia; y, las que basan sus ideas en que la Constitución posee la capacidad suficiente para imponer los intereses que el ordenamiento penal debe acoger ${ }^{68}$. Si bien en la doctrina española ninguna de ellas ha conseguido imponerse claramente, cabe la posibilidad de adoptar una postura intermedia y conciliadora que combine la dañosidad social con el referente constitucional, pues resultando indiscutible el origen social del bien jurídico, también resulta incuestionable que la determinación de aquello que merece tutela penal no puede depender exclusivamente de una decisión del legislador.

\section{V.1. El bien jurídico colectivo seguridad vial}

La nueva política criminal se va a caracterizar por la intervención en nuevas zonas construidas en torno a bienes jurídicos de titularidad social o colectiva, impulsada por la sociedad del riesgo, con unas características distintas a las propias de los bienes jurídicos individuales, pues parece claro que en la sociedad actual la existencia

65 Al respecto, véase Villegas Paiva, Elky Alexander, "Los bienes jurídicos colectivos en el Derecho Penal. Consideraciones sobre el fundamento y validez de la protección penal de los intereses macrosociales”, Editorial Astrea, 2010, págs. 18-19.

${ }_{66}$ Mir Puig, Santiago, "Bien jurídico y bien jurídico-penal como límites del Ius puniendi", Estudios Penales y Criminológicos, n 14, 1989, pág. 207.

67 VARgas Pinto, T., op. cit., págs. 78-79.

68 Sobre el particular, véase CARo Coria, Dino Carlos y REYNa AlFaro, Luis MiGuel, Derecho penal económico. Parte General - Tomo I, Juristas Editores E.I.R.L., Lima-Perú 2016, págs. 278-298. 
de bienes de naturaleza supraindividual se va a convertir en esencial. Pero esta selección de los bienes jurídicos dignos de tutela penal debe centrarse en criterios materiales, en clave sociológica en función del valor socialmente reconocido, y no políticos, si no queremos incurrir en lo que algunos autores han venido a denominar la "progresiva hipertrofia penal del Estado Social"69.

Se podría decir que la delimitación entre los bienes jurídicos individuales y los colectivos se basaría en el concepto de "no distributividad", no siendo posible dividir el bien jurídico colectivo en diferentes partes que luego pudieran ser asignadas a cada individuo, caracterizándose éstos por poder ser disfrutados por cada miembro de la sociedad sin exclusión, no dándose tampoco rivalidad en su consumo y no existiendo perjuicio ni impedimento en su uso o disfrute por parte de varios individuos a la vez ${ }^{70}$.

Lo característico de estos bienes jurídicos colectivos va a ser la titularidad compartida por una generalidad de personas en base a las nuevas necesidades de protección jurídica que tienen su origen en las realidades sociales colectivas. Todos los miembros de la sociedad van a compartir un mismo interés a la hora de conservar y respetar una determinada situación, tratándose de circunstancias en la que todos o una parte de la sociedad se van a encontrar, precisando del respeto en interés del conjunto ${ }^{71}$.

No resulta uniforme la doctrina a la hora de admitir una relación entre los bienes jurídicos colectivos y los individuales, si bien la opinión mayoritaria parte de la base de que "los bienes colectivos van a tener relevancia penal en la medida en que su protección constituya una condición indispensable para salvaguardar intereses individuales"72. De este modo los bienes jurídicos colectivos se van a concebir como bienes con un referente personal, pues si carecieran de él no podría dotarse de suficiente contenido al bien jurídico para justificar la intervención penal.

69 Cuesta Pastor, P., op. cit., pág. 61.

70 Véase Gracia Bogado, María y Ruth Ferrari, Débora, "Sociedad de riesgo: legitimación de los delitos de peligro hipotético", Centro de Investigación Interdisciplinaria en Derecho Penal Económico, 2009, págs. 5-6. Recuperado el 4 de agosto de 2021 de http://ciidpe.com.ar/area1/Delitos\%20de\%20aptitud.Ferrari.pdf; También Villegas Paiva, E. A., op. cit., pág. 7.

71 VARGAS PinTo, T., op. cit., pág. 104-106.

72 Véase CARnEVAli RodríguEZ, Raul, "Algunas reflexiones en relación a la protección penal de los bienes jurídicos supraindividuales", Revista Chilena de Derecho, vol. $27 \mathrm{n}^{\circ} 1,2000$, pág. 142. 
Los bienes jurídicos colectivos deben ser entendidos como complementarios de los bienes individuales, hallándose por ello al servicio de éstos como en el caso de la vida humana o la salud ${ }^{73}$, y gozan de un carácter instrumental o teleológico que hace difícil concebir su existencia como autónoma e independiente del ser humano ${ }^{74}$. Van a ser por lo tanto considerados como tales en cuanto medios que van a posibilitar la vida y desarrollo del individuo en la sociedad, existiendo por ello una vinculación con aquellos bienes individuales que presenten aspectos de relevancia social.

La moderna sociedad del riesgo ha hecho surgir nuevas realidades sociales que de manera anónima van a afectar a aquellos bienes individuales que dieron origen al Derecho penal de la Ilustración, dando impulso ahora a la creación de bienes jurídicos colectivos que vienen a cubrir nuevas necesidades de tutela personal, quedando por ello vinculados a los bienes jurídicos individuales sin cuya existencia no tendrían objeto. Estos bienes individuales se verían afectados de una manera mediata mientras que los bienes colectivos resultarían inmediatamente perturbados.

Este es el caso de los delitos contra la seguridad vial que se encuentran recogidos en el Título XVII del Libro Segundo del Código Penal, bajo la rúbrica genérica de "Delitos contra la seguridad colectiva”, que como cualquier otro Código desempeña una función sistemática, de ordenación y clasificación de las diversas figuras delictivas, y dentro de este Título más concretamente en su Capítulo IV, que pretende delimitar su ámbito aplicativo y apuntar hacia cuál puede ser el objeto de protección. Esta seguridad colectiva representa una necesidad de protección que se desprende de la aceptación por parte de la sociedad de lo que ha venido en llamarse la sociedad del riesgo ${ }^{75}$.

Hoy día no se discute por la doctrina dominante que el bien jurídico protegido sea la seguridad vial y así lo consideran también

73 Villegas Paiva, E. A., op. cit., pág. 19; también Terradillos Basoco, J., op. cit., pág. 84 .

${ }^{74}$ En este sentido, véase Rodríguez FERnández, Ignacio, La conducción bajo la influencia de bebidas alcohólicas, drogas tóxicas, estupefacientes y sustancias psicotrópicas, Editorial Comares, Granada 2006, pág. 43.

75 Con el concepto o expresión seguridad vial lo que se busca es la reducción del riesgo en la conducción, debiendo concebirla como una parte del conjunto de la seguridad pública que incluye todas las actividades dirigidas a la protección de personas y bienes y al mantenimiento de la tranquilidad ciudadana (art. 2.3 de la LO 4/2015 de protección de la seguridad ciudadana). 
tanto la jurisprudencia ${ }^{76}$ como la Fiscalía General del Estado ${ }^{77}$, centrándose el debate más en su contenido y naturaleza.

Por otra parte, ninguna de las diferentes posturas doctrinales en relación con el bien jurídico colectivo seguridad vial llega a concebirlo de un modo absoluto haciendo uso solo de una perspectiva autónoma o personalista, buscando siempre algún tipo de relación con otros bienes jurídicos individuales, colocando a este bien colectivo con una referencia directa a estos otros bienes ${ }^{78}$.

Se podría afirmar que el bien jurídico colectivo seguridad vial goza de un carácter intermedio ${ }^{79}$, constituyendo un mero instrumento que sirve a la protección de otros bienes jurídicos individuales, la vida e integridad física de las personas ${ }^{80}$. Y esta parece ser la postura más acertada viendo la referencia explícita que hacen los artículos 380 y $381 \mathrm{CP}^{81}$ sobre el objeto jurídico de protección ${ }^{82}$.

76 Por todas, Tribunal Supremo (Sala de lo Penal). Sentencia núm. 369/2017 de 22 de mayo de 2017, fundamento jurídico $4^{\circ}$.

77 Véase, Fiscalía General del Estado, Circular 10/2011 sobre criterios para la unidad de actuación especializada del Ministerio Fiscal en materia de seguridad vial, Ministerio Fiscal, Madrid 2011, págs. 6-7.

78 En este sentido, véanse Molina Fernández, Fernando, Delitos contra la Seguridad Vial: su aplicación jurisprudencial, Ediciones Francis Lefebvre, Madrid 2014, págs. 12-14: De Vicente Martínez, Rosario, Derecho Penal de la Circulación, Editorial Bosch, Barcelona 2008, pág. 321; Hernández Plasencia, José Ulises, “Delitos de peligro con verificación de resultado: ¿concurso de leyes?, Anuario de derecho peal y ciencias penales, vol. 47 n 1, 1994, págs. 119-122; RODRÍGUEZ FERNÁNDEZ, I. op. cit., pág. 43; CEREzo MiR, J., (2002), op. cit., pág. 58; VARGAS PINTO, T., op. cit., págs. 128-130; Gómez Pavón, P., op. cit., pág. 89.

79 Se coincide aquí con VARGAS PINTO, T., al entender que con esta expresión se está haciendo referencia a una especial técnica legislativa y no a una clase especial de bien jurídico-penal, distinto de los individuales y los colectivos, se trata de una especial forma de protección de bienes colectivos vinculados a la tutela de otros bienes jurídico-penales.

80 En esta misma línea Cerezo Mir, J., (2002), op. cit., págs. 56-57; Fiscalía General del Estado, op. cit., págs. 6-7; Maldonado Fuentes, F., op. cit., págs. 50-52.

81 En estos dos artículos se castigan conductas que ponen en concreto peligro la vida o la integridad de las personas así como que supongan un manifiesto desprecio por la primera.

82 El propio Preámbulo de la LO 15/2007 por la que se modifica la LO 10/1995 del Código Penal en materia de Seguridad Vial, también apunta a cual deben ser los objetos de protección al hacer mención expresa respecto del artículo $382 \mathrm{CP}$ a la "específica regla para salvar el concurso de normas cuando se hubiere ocasionado además del riesgo prevenido un resultado lesivo", contemplando realmente un concurso de delitos para el que el legislador prevé una regla especial ajena al sistema general de resolución de concursos, resolviendo así la concurrencia de un delito de peligro contra la seguridad vial y otro de resultado de lesión para la vida o la integridad; véase en este sentido Tribunal Supremo (Sala de lo Penal). Sentencia núm. 64/2018 de 6 de febrero de 2018, fundamento jurídico único. 
$\mathrm{Al}$ hacer uso de un bien jurídico protegido como instrumento para la tutela de otro de naturaleza distinta, lo que se está haciendo es adelantar la barrera defensiva del Derecho penal, y si para esta protección se recurre a la técnica del delito de peligro abstracto lo que se consigue además es ampliar aún más el alcance de esta anticipación.

La referencia del bien jurídico colectivo seguridad vial a la vida y a la integridad de las personas se va a presentar de este modo respetuoso con el principio de ofensividad, a la vez que justificaría la intervención penal como ultima ratio, precisamente al exigirse que esa tutela penal se extienda a valores que conserven esa referencia individual.

Según lo ya visto, un análisis de la última modificación del Código Penal introducida por la LO 2/2019 y que viene a insertar un nuevo precepto, el artículo 382 bis $\mathrm{CP}^{83}$, presentaría serias dudas acerca de cuál sería el bien jurídico protegido en este nuevo delito de fuga en el ámbito de la seguridad vial, "utilizando el legislador una terminología más propia de un juicio de censura desde le Ética o la Moral que desde el Derecho" ${ }^{84}$, al hacer referencia expresa en el preámbulo de la citada Ley Orgánica a que "lo que se quiere sancionar en este caso es la maldad intrínseca en el abandono de quien sabe que deja atrás a alguien que pudiera haber lesionado o incluso fallecido, la falta de solidaridad con las víctimas". Pero el Derecho penal, como ya se ha dicho antes, está para proteger bienes o intereses merecedores de protección para el desarrollo del individuo en el seno de la sociedad y no conductas consideradas socialmente como

\section{Artículo 382 bis CP}

El conductor de un vehículo a motor o de un ciclomotor que, fuera de los caos contemplados en el artículo 195, voluntariamente y sin que concurra riesgo propio o de terceros, abandone el lugar de los hechos tras causar un accidente en el que falleciera una o varias personas o en el que causare lesión constitutiva de un delito del artículo 152.2, será castigado como autor de un delito de abandono del lugar del accidente.

Los hechos contemplados en este artículo que tuvieran su origen en una acción imprudente del conductor, serán castigados con la pena de prisión de seis meses a cuatro años y privación del derecho a conducir vehículos a motor y ciclomotores de uno a cuatro años.

Si el origen de los hechos que dan lugar al abandono fuera fortuito le corresponderá una pena de tres a seis meses de prisión y privación del derecho a conducir vehículos a motor y ciclomotores de seis meses a dos años.

84 De Vicente Martínez, Rosario, Siniestralidad vial, delitos imprudentes y fuga, REUS, Madrid 2019, págs. 134-135, para esta autora, "vistas las semejanzas y diferencias entre el art. $195 \mathrm{CP}$ y el nuevo art. 382 bis CP, la conclusión a la que se llega es que seguramente no era necesario introducir un nuevo tipo penal, bastando con reformar el vigente artículo $195 \mathrm{CP}$ si lo que realmente se quería esa penalizar la huida del lugar del accidente o bien, remitir esta materia al ámbito del Derecho administrativo sancionador reforzando las sanciones". 
éticas o morales en cada momento histórico o político, pues la ética o la moral social no deben imponerse desde el Derecho penal.

Pero al margen de esta nueva tipología delictiva, también resulta complejo identificar cual sería el bien jurídico protegido en el caso de las conductas recogidas en los artículos 383 y $384 \mathrm{CP}^{85}$, aunque parece claro que éste no debería ser la seguridad vial de manera inmediata, ni la vida o integridad de las personas de manera mediata, aproximándose más a una desobediencia grave o a diferentes tipos de quebrantamientos, ambos incluidos ahora en el ámbito específico de los delitos contra la seguridad vial ${ }^{86}$.

\section{CONCLUSIONES}

1. La realidad social que representa la inseguridad vial hace necesario su abordaje desde el Derecho penal en esa ineludible expansión que viene experimentando desde mediados del siglo xx.

2. La expansión del Derecho penal hacia estos nuevos riesgos no debe suponer un abandono de las reglas de imputación ni de los principios que deben regir el ius puniendi del Estado, debiendo limitarse este recurso del ordenamiento jurídico a la exclusiva protección subsidiaria y fragmentaria de bienes jurídicos como ultima ratio.

85 Artículo $383 \mathrm{CP}$

El conductor que, requerido por un agente de la autoridad, se negare a someterse a las pruebas legalmente establecidas para la comprobación de las tasas de alcoholemia y la presencia de drogas tóxicas, estupefacientes y sustancias psicotrópicas a que se refieren los artículos anteriores, será castigado con las penas de prisión de seis meses a un año y privación del derecho a conducir vehículos a motor y ciclomotores por tiempo superior a uno y hasta cuatro años.

Artículo 384 CP

El que condujere un vehículo de motor o ciclomotor en los casos de pérdida de vigencia del permiso o licencia por pérdida total de puntos asignados legalmente, será castigado con la pena de prisión de tres a seis meses o con la multa de doce a veinticuatro meses o con la de trabajos en beneficio de la comunidad de treinta y uno a noventa días.

La misma pena se impondrá al que realizare la conducción tras haber sido privado cautelar o definitivamente del permiso o licencia por decisión judicial y al que condujere un vehículo de motor o ciclomotor sin haber obtenido nunca permiso o licencia de conducción.

86 Véase Mingorance Sánchez, José A., op. cit., págs. 443-448. 
3. La antijuridicidad de las conductas típicas de peligro (concreto y abstracto) debe incluir tanto un desvalor de la acción como un desvalor del resultado. En la apreciación de este último la doctrina parece inclinarse hacia la creación de un peligro concreto para el bien jurídico en el primero de los casos, o, para el caso de los delitos de peligro abstracto, que la conducta peligrosa escape al control, dominio o gobierno del que la ejecuta, colocando de este modo al objeto de protección en una posición muy próxima a la lesión en donde el autor ya nada podría hacer para evitarlo.

4. Respecto al objeto de protección ante estas nuevas demandas sociales, la solución dada por el legislador ha sido la creación de nuevos bienes jurídicos colectivos, que, unido al recurso a la técnica legislativa de los delitos de peligro, lo que pretenden es adelantar las barreras de protección a determinados bienes jurídicos individuales considerados esenciales. Bienes colectivos que necesariamente deben tener un referente individual que en el caso de la seguridad vial serán la vida y la integridad de las personas.

5. Vistas estas primeras conclusiones, parece claro que el Derecho penal debe abordar el problema social que representa la inseguridad vial, debiendo exigirse una antijuridicidad material que se concretaría en la afectación de manera mediata de los bienes jurídicos individuales vida e integridad de las personas. Según esto no encontraría justificación jurídica alguna la incardinación de los tipos recogidos en los artículos 382 bis, 383 y $384 \mathrm{CP}$, al no afectar ninguno de ellos al bien jurídico colectivo seguridad vial ni mucho menos a los bienes individuales vida e integridad de las personas. Pero es que además, el recurso a estos ilícitos como de peligro abstracto requeriría en primer lugar un desvalor de la acción que, aun en el caso de que ésta se llegara a considerar peligrosa, debería ir seguido de un desvalor del resultado, es decir, una situación de peligro para el objeto protegido, algo que tampoco se observa en ninguna de las conductas descritas en los tipos penales referidos.

6. Como propuestas de lege ferenda se apuntan en primer lugar la desaparición del art. 382 bis CP, al considerar que esta conducta ya encuentra su reproche penal en el art. 195.3 CP referido a la omisión del deber de socorro del causante de un accidente; y en segundo lugar se estima que las conductas recogidas en 
los arts. 383 y 384 CP no debieran haber traspasado el umbral del Derecho administrativo sancionador por los motivos ya expuestos. Cosa distinta son el resto de los tipos penales recogidos como delitos contra la seguridad vial que sí encontrarían justificación desde el punto de vista jurídico-penal según lo ya argumentado, sin querer entrar en el debate sobre su revisión respecto a la técnica jurídica utilizada o actualización a las nuevas evidencias científicas conocidas, que no es el objeto del presente trabajo. 